\title{
The Fading Right to Property in India
}

\author{
By Gopal Sankaranarayanan, New Delhi*
}

The history of India and its Constitution is writ in superlatives. From the longest text to the largest democracy, the six decades since India became a republic have been eventful ones. In 2011, it has the world's greatest backlog of pending cases ${ }^{1}$, and a Supreme Court so strident and contradictory that reducing that dubious statistic will be no easy task. For a nation that ranks very low on virtually every single human development index ${ }^{2}$, the access to the most basic rights becomes an insurmountable task. The right to food, shelter and clothing were read into the provision that recognizes the right to life of every individual (Article 21), but even that was some time coming. ${ }^{3}$ In express terms at the inception, accommodation was made in the Constitution for certain so-called 'Fundamental Rights', broadly covering four segments - individual equality, individual liberty, individual civil rights, and community right to faith and education. A violation of any of these rights could be agitated directly in the Supreme Court courtesy Article 32 of the Constitution which "guaranteed" such a protection. The unprecedented insertion of a provision (Article 13) that permitted the courts to declare a duly enacted law void on the ground that it breached any one or other of the Fundamental Rights was the first sure step in the direction of true judi-

Gopal Sankaranarayanan is Advocate of the Supreme Court of India and Member, Indian Society of International Law.

1

Just over 4.1 million cases at the superior courts (the Supreme Court and the 21 High Courts) and about 27.8 million at the district and subordinate courts, as per Court News, Vol.V, Issue No.3, July-September 2010, at pp.5-7.

According to the Human Development Report, 2010 of the United Nations Development Programme, India is ranked 119 in the world on indices that include poverty, health, education and sustainability. The Report's country profile of India with detailed trends may be accessed at http://hdrstats.undp.org/en/countries/profiles/IND.html

The narrow interpretation to Article 21 afforded by the Supreme Court in A.K.Gopalan v. State of Madras, [1950] Supreme Court Reports 88, was premised on the fact that the Indian Constitution lacked a due process clause. The departure from this simplistic approach was made in Maneka Gandhi v. Union of India, (1978) 1 Supreme Court Cases 248, where the scope of Article 21 was widened to include several aspects hitherto not explicitly found in the Constitution. One author has attributed this not to a sudden shift in judicial mindset but to a gradual transformation due to the importation of norms from foreign jurisdictions over the intervening three decades. See Manoj Mate, The Origins of Due Process in India: The Role of Borrowing in Personal Liberty and Preventive Detention Cases, Berkeley Journal of International Law, Vol.28:1, 2010, p.216.

4 Chapter III of the Constitution dealing with Fundamental Rights strongly echoes the sentiments laid down in the Universal Declaration of Human Rights, 1948 and anticipates the provisions of the International Covenant on Civil and Political Rights, 1966. 
cial review. ${ }^{5}$ However, the years that followed bore witness to the fact that the conflict between the judiciary and the legislature revolved around their respective interpretation of the right to property.

\section{A. Property in India}

Ever since civilization began many millennia ago, the quest for accumulation has been ingrained in man's avarice. First came the individual's hunt for food and shelter, and then, with societies and city-states, the idea of community took root. In Rome, the triumvirates came and went, as did the Republic in Greece. With the emergence of larger identities, there was the need to sanctify and secure the common ideal. From merely being a source of food and sustenance, the finite attributes of property (geography, utility, residence) led to it being treated more as an asset with a real value. Group and national ownership emerged, the former resting on Government regulation, while the latter was more ad-hoc, veering between covenants and conquest.

The earliest traces of regulation involving property and its ownership are found in the Babylonian Code of Hamurrabi. ${ }^{6}$ Much like in other parts of the world, land was tilled by others on behalf of the owners, and all land was deemed to be owned by the ruler. Accounts by Plato in Greece and the Codex of Justinian in Rome show that the civilizations of Europe had gradually come to embrace the private and individual context of property. In many of these, the systems of holding of property sowed the seeds of feudal ownership and land tenures. ${ }^{7}$ In India, the Code of Manu that evolved around the $5^{\text {th }}$ century B.C., narrates how the four castes of the Hindu religion had distinct ways of gaining ownership of land. The Brahmin priests obtained it through religious practices and sacrifices, the warrior Kshatriyas by conquest, and the trader Vaisyas and Sudras through income from their business. Wives, sons and slaves were not given the right to own property, as they were themselves considered the property of others! $!^{8}$ As recorded by Elphinstone ${ }^{9}-$

See also, Gopal Sankaranarayanan, Man Damn Us, 9 (2009) Supreme Court Cases (Journal), p. 6.

The Code was created around the $18^{\text {th }}$ century B.C. by Hamurrabi, the sixth king of Babylon. Carved on a stele presently stored at the Louvre, the Code is much more than the commonly understood basis for pure retribution. While several of the 282 sections of the Code deal with penal provisions, many others relate to marriage and divorce, price regulation, contracts, building operations and army service. It is somewhat ironic that while there existed a strict class system based on ownership of property, and there were visible traces of feudalism, the Code itself is silent on what actually were the rights held in property.

For a detailed account of more than 31 ancient cultures and their regulation of property relations, see Mohammed Hidayatullah, Right to Property and the Indian Constitution, New Delhi 1986, at pp.31-70.

8 Echoes of this view may be found in the decision of the United States Supreme Court in Dred Scott v. Sandford, 60 U.S. 393 (1857), where slaves were held to be property, and therefore could never be considered citizens for the enjoyment of Constitutional protections. Abraham Lincoln led 
"Property in land seems to consist in the exclusive use and absolute disposal of the powers of the soil in perpetuity, destroy the soil where such act is possible. These privileges combined form an abstract idea of property which does not represent any substance distinct from these elements. Where they are found united there is property and nowhere else."

The notion of identifying property with land was one that abided, even right up to the coming of the Indian Constitution. Little attention was paid to incorporeal or moveable property, with the laws concerning them relating primarily to penal regulation for theft and burglary. Unfortunately, much of the legal regimes extant in pre-British India were poorly catalogued, and so, barring the passing advertence, information right up to the $17^{\text {th }}$ century has been modest. The era of colonial rule suffered from no such malaise. With the swiftness that marked British expediency, first the East India Company and later the crown vested in themselves the very same rights to property hitherto enjoyed by the native ruler. The State would retain rights to revenue, escheat and to make grants, at all times recognizing traditional and ancient practices enjoyed by the individuals concerned.

The Indian feudal system at this point of time was a varied one, with different relationships and arrangements existing between the owner of the land and the actual user. Raiyatwars, zamindars, talukdars, janmis and jagirdars predominated, with Inams and Muafis also serving the same purpose, albeit without the payment of land revenue. ${ }^{10}$ British rule brought with it first certain permanent settlements and grants in perpetuity, but without any explicit recognition of a Constitutional right to property. Certain laws abolished the feudatory rights of local chiefs and landlords, and no recourse was available against such governmental action. As noticed by Hidayatullah, the system of valuation of land that was taken from private individuals was left to certain 'arbitrators' who were prone to both corruption and ineptitude. ${ }^{11}$ It was to repair this that the British Parliament intervened first in 1870, and then in 1894 with the Land Acquisition Act. ${ }^{12}$ Barring a few cosmetic changes, it is this law that is still enforced in India today, and the source for much rancour from the depressed sections whose lands are taken for paltry recompense.

the voices raised in criticism of the decision, and this finally led to the Thirteenth, Fourteenth and Fifteenth Amendments after the Civil War.

Mountstuart Elphinstone, History of India, New Delhi 2002, p.137.

10

All these expressions refer to the various forms to land holdings in British India. Most commonly, a large landholder would own the land on which tilling would be carried out by farmers, who would not own the land, but pay revenue to the landlord, who would then pay a part to the king or government, retaining a certain portion for himself. One of the most comprehensive discourses on this topic is B.H.Baden Powell's The Land Systems of British India, London 1892.

Hidayatullah, supra n. 7, at pp.125-126.

12 This period of about 3 decades saw several important laws passed by the sovereign, which are still applied in India today. A few of these are the Indian Penal Code of 1860, the Evidence Act of 1872, the Indian Contract Act of 1872, the Carriers Act of 1865 and the Easements Act of 1882. 


\section{B. Creating a Constitutional Right}

The precursor to the Indian Constitution was the Government of India Act, 1935, which was a document based on several Reports of Parliamentary and other governmental bodies regarding the most efficient means of administering a nation like India. ${ }^{13}$ Although the Land Acquisition Act reflected the principle of eminent domain and provided that the taking of land was permissible only in public interest and upon payment of compensation (cf. sections 3(f), 4, 6 and 11 of the Act), the right to own property itself was not available from the Government of India Act or from constitutional convention. It was suggested by a Joint Parliamentary Committee, created expressly for this purpose and comprising members of both the British House of Commons and House of Lords, that $-{ }^{14}$

"We think that some general provision should be inserted in the Constitution Act, safe-guarding private property against expropriation, in order to quiet doubts which have been aroused in recent years by certain Indian utterances. It is obviously difficult to frame any general provision with this object without unduly restricting the powers of the Legislature in relation particularly to taxation; in fact, much the same difficulties would be presented as those which we have discussed above in relation to fundamental rights.

We do not attempt to define with precision the scope of the provision we have in mind, the drafting of which will require careful consideration for the reasons we have indicated; but we think that it should secure that legislation expropriating, or authorizing the expropriation of, the property of particular individuals should be lawful only if confined to expropriation for public purposes and if compensation is determined, either in the first instance or on appeal, by some independent authority.General legislation, on the other hand, the effect of which would be to transfer to public ownership some particular class of property, or to extinguish or modify the rights of individuals in it, ought, we think, to require the previous sanction of the Governor-General or Governor (as the case may be) to its introduction; and in that event he should be directed by his Instrument of Instructions to take into account as a relevant factor the nature of the provisions proposed for compensating those whose interests will be adversely affected by the legislation."

Much attention would not normally be paid to these documents, especially when the Government of India Act existed for a mere 15 years until it was replaced by the present Constitution. However, it was as a result of these recommendations and discussions that property rights were first sanctified in the Constitution. The first and last clauses of Section 299 of the Government of India Act as enacted are relevant for this discussion:

The Act was enacted by the British Parliament and is annotated as '26 Geo.5, Ch.2'. As it existed for only 15 years, there is limited literature on it. The best commentary is N. Rajagopala Ayyangar, The Government of India Act, 1935, Madras 1937. The problems faced by the Governments that sought to administer India have remained unaltered since ancient times. From the time of Ashoka (304-232 BC), the great Mauryan king who first brought the entire subcontinent under his rule, to the Mughals and the British, the vastness of the land, the multifarious cultures and languages, the inhospitable terrain, the variety of industries and the traditional forms of ownership have made legal regulation of the entire nation a difficult task.

14 Report of the Joint Parliamentary Committee on the Government of India Act 1935, cf. Chetandas Gulabchand v. The State of Bihar, All India Reporter 1958 Patna 512. 
"299(1) No person shall be deprived of his property in British India save by authority of law. (5) In this section land includes immovable property of every kind and any rights in or over such property, and 'undertaking' includes part of an undertaking."

It was thus clear that holders of both moveable and immoveable property received the protection under the Constitution. The fact that this right was of higher currency than others was reinforced not by a license to exercise it, but by a bar being imposed on the State not to deprive its enjoyment. This very recognition placed property on a high pedestal, which correctly reflected the thinking of a time when the British were besieged by resistance from its colonies, and when the small landholders were sought to be protected.

As India attained independence from Britain in 1947, one of the first steps towards establishing the new nation had been the creation of a Constituent Assembly ${ }^{15}$, charged with enacting a Constitution for the world's largest democracy. Buoyed by a socialist zeal which had been the product of Mahatma Gandhi's philosophy, it was concluded that social justice would be a primary goal of the new Constitution. Towards this end, the draftsmen created separate chapters for the basic justiciable tenets (Fundamental Rights) and for the values that India would cherish (Directive Principles of State Policy). Provisions relating to gender equality, representation for the depressed castes, protection for minority institutions and the penalization of exploitative practices found place in these two Chapters of the Constitution, with certain provisions enshrining justiciable rights, others non-justiciable goals.

The backbone of the Constitution was seen to be the Fundamental Rights chapter ${ }^{16}$, in which two separate provisions dealt with the right to property. Article 19(1), which dealt with the liberties available to individuals, protected via sub-clause (f) the right of an individual to acquire, hold and dispose of property. In addition, Article 31 reproduced Section 299 of the Government of India Act and preserved the eminent domain principle. However, there are 2 important points to be borne in mind when examining Article 31:

(i.) This provision, along with Article 21 which preserved the right to life are two singular provisions in the Indian Constitution which do not bestow rights, but in fact recognize and declare as inherent the rights to life and to property. In this, other provisions like those dealing with equality (Article 14) and liberty (Article 19) contrastingly treat the respective rights as emanating from the Constitution.

(ii.) In addition, while most of the other rights are specifically available only to citizens of India, rights of life, equal treatment and property were made available to any person, thereby including non-citizens as well.

The Constituent Assembly commenced functioning from as early as December 1946, several subCommittees on various sections started work in January 1947, and the Drafting Committee came 16 into existence on $29^{\text {th }}$ August 1947, a fortnight after India gained independence.

Part III of the Constitution, which comprises Articles 12 to 35. 
The fact that the right to property was therefore initially conceived to be a pre-eminent and crucial tenet is bolstered by an advertence to the history of the debates leading to its accommodation in the Constitution.

The Constitutional Adviser to the Constituent Assembly and the architect of the Draft Constitution was Sir B.N.Rau, a distinguished former civil servant and constitutional expert who was later to adorn the Permanent Court of International Justice at The Hague. In the comparative research undertaken by him to suitably supplement the provisions of the Government of India Act and form a basis for the new Constitution, Sir Rau referred extensively to the laws of Europe, Australia and North America. In doing so, he observed thus -17

"The difficulty is in defining the precise limits in each case (of a fundamental right) and in devising effective protection for the rights so limited. Some of the Constitutions have attempted to define the limits of some of these rights and in doing so have gone far towards destroying them. As an example, we may take Article 153 of the German Constitution, which runs: 'Property is guaranteed by the Constitution. Its extent and the restrictions placed upon it are defined by law. Expropriation may be effected only for the benefit of the general community and upon the basis of law. It shall be accompanied by due compensation save in so far as may be otherwise provided by a law of the Reich."”

In effect, opined Rau, even though the right to private property was "guaranteed" and treated as inviolable, such assurances were meaningless where the property could be taken through the process of law. Initially, after much deliberation, and after acknowledging the debt to Amendments V and XIV of the American Constitution, the Sub-Committee on Fundamental Rights submitted its final report to the Constituent Assembly on April 16, 1947. In this Report, the right to property was inserted along with life and liberty in Clause 12 (later to be Article 21). Further, Clause 26 made it clear that no property could be taken for public use without the payment of just compensation. ${ }^{18}$ One of the members, Sardar K.M. Panikkar suggested the disassociation of property from life and liberty as a possible solution to the various challenges anticipated from the zamindars (landowners), and this met with the approval of legal stalwarts K.M. Munshi, B.R. Ambedkar and C. Rajagopalachari. $^{19}$

Eventually, after changes were recommended by the Assembly, the Drafting Committee placed a provision concerning the right to acquire and hold property with the liberties enshrined in Draft Article 13, which was finally approved and re-numbered as Article 19 of the Constitution. ${ }^{20}$ Clause 26 became Draft Article 24, and was eventually adopted as Article 31 , with compensation to be fixed, or the principles for the same to be clearly

Supra n. 7, at p.137. The "German constitution" Rau refers to is the Weimar Constitution of 1919. Shiva Rao, The Framing of India's Constitution, Vol. II, Delhi 1968, at pp.169-198.

20 Constituent Assembly Debates, Vol.VII, Lok Sabha Secretariat, Delhi, (1949) at pp. 40-41 \& 730789. 
specified. $^{21}$ This provision corresponded almost identically to Section 299 of the Government of India Act and allowed any perceived transgression of it to be agitated directly in the Supreme Court ${ }^{22}$. There had been considerable division within the ruling Congress party regarding the extent of court interference and the quantum of compensation, but it was largely felt that the final version of Article 31 was a compromise suitable to all. ${ }^{23}$ Concurrent with the Constitution, Jawaharlal Nehru's government delivered on its promise of land reform, and hundreds of laws were enacted by the states providing for the abolition of zamindari rights and for nationalizing certain private enterprises. Many of these laws can be found in the $9^{\text {th }}$ Schedule to the Constitution.

\section{The Erosion}

Barely months after the Constitution came into force, it's property provisions were invoked by individuals in the northern States of Bihar, Uttar Pradesh and Madhya Pradesh to challenge the respective land reform legislations of those states. The first reverse suffered by the Government was by courtesy of the High Court of Bihar which struck down as unconstitutional the Bihar Management of Estates and Tenures Act, 1949 for being unreasonable in not providing for compensation and being generally onerous. ${ }^{24} \mathrm{~A}$ few months later, it was the turn of the High Courts of Lucknow and Allahabad in Uttar Pradesh to issue orders restraining the Government from acquiring lands under that State's land reforms law. ${ }^{25}$ In a sign of things to come, Prime Minister Nehru wrote to the Chief Ministers saying, "[I]f the Constitution itself comes in our way, then surely it is time to change that Constitution." 26 Shortly thereafter, a judgment of the Calcutta High Court rejected the stand of the Government that compensation for land calculated as of the date of notification for acquisition in 1946, although taken over in 1950 would be valid. ${ }^{27}$ This was found not to be just compensation, and hence violative of Article 31 . Understandably agitated that the much-touted land reform programme was beginning to go awry, the Government promptly set about amending the Constitution to circumvent the judgments handed down. By way of the First Amendment to the Constitution, Articles 31A and 31B were inserted in Part III, which

21

Constituent Assembly Debates, Vol.IX, Lok Sabha Secretariat, Delhi, (1949) at pp. 505-518 \& 1191-1302; see also Shiva Rao, supra n.18 at pp. 281-301.

22

23

24

25

26

26

27

Article 32 provides for a direct approach to the apex court of the country in the event of a breach of any of the fundamental rights enshrined in Part III of the Constitution.

See generally, Granville Austin, The Indian Constitution - Cornerstone of a Nation, Oxford 1972, at pp. 87-99.

Kameshwar Singh v. The Province of Bihar, All India Reporter 1950 Patna 392.

Granville Austin, Working a Democratic Constitution, Oxford 1999, at pp. 80-81.

Letter of 1.2.1951, Nehru's Letters to Chief Ministers, Vol.2, Delhi 1997, p. 325.

The West Bengal Settlement Kanungo Cooperative Society v. Bela Banerjee \& Ors., All India Reporter 1951 Calcutta 111. 
excluded judicial review where laws sanctioned the taking over of estates, and also provided a Schedule ${ }^{28}$ in which all central and provincial laws vulnerable to constitutional challenges could be placed for judicial immunity.

Nehru's actions, though probably justified at the time, showed a lack of prescience, because with one fell blow, he created two mechanisms by which the supremacy of Parliament would be emphasized - (a) the power of the Constitutional Amendment to nullify the judgments of the courts, used for the first time in this instance, and (b) the Ninth Schedule, by which the very power of judicial review of legislative action (one accorded by the Constitution itself) would be excluded. In the years to come, these two instruments more than any other would be used by less responsible Governments to trammel the judiciary and muzzle the electorate. ${ }^{29}$ On the issue of property rights alone, much of Indian public law jurisprudence has evolved. In what could well be a unique history of conflict between the legislative and the judiciary, a series of Constitutional amendments were carried out with the sole objective of neutralizing the effect of judicial interpretation of the Constitution. In the two and a half decades during which Article 31 continued in force, this trend was in evidence on six separate occasions, the first of which has been detailed above. The rest are considered in brief here:

(i) In the wake of the judgment of the Supreme Court in Bela Banerjee's case ${ }^{30}$, where it was held that the owner of expropriated property must be paid full 'market value' as compensation, Parliament enacted the Constitution ( $4^{\text {th }}$ Amendment) Act, 1955 by which an insertion was made in Article 31(2) to the effect that "no such law shall be called in question on the ground that the compensation provided by that law not adequate".

(ii) In I.C. Golak Nath's case ${ }^{31}$, the Constitution (17 $7^{\text {th }}$ Amendment) Act was challenged, which had inserted the offending Punjab Land Tenures legislation in the Ninth Schedule, and resulted in a deprivation of the fundamental right to own and enjoy property. Invoking the principle of prospective overruling, the Court concluded that no Constitutional amendment could alter any of the fundamental rights. This radical position was sought to be reversed by the passage of the Constitution (24 ${ }^{\text {th }}$ Amendment) Act, 1971.

(iii) At the same time, challenges to the quantum of compensation continued, and the Supreme Court again observed that the very word 'Compensation' itself indicated only 'full compensation'. This observation in the Bank Nationalization Case ${ }^{32}$ prompted the

The Ninth Schedule, which was appended to Article 31-B may have commenced existence with the noblest of intentions and the insertion of 13 land reform laws that sought immunity. However, over the years, this provision has been subject to abuse, being amended several times, leading to it now protecting 284 legislations, many of whom have no nexus with land reforms at all. Supra n.5.

State of West Bengal v. Bela Banerjee, 1954 Supreme Court Reporter 558

31 I.C.Golak Nath v. State of Punjab, [1967] 2 Supreme Court Reporter 763. 
Government to enact the Constitution ( $25^{\text {th }}$ Amendment) Act, 1971 whereby the word 'Compensation' in Article 31(2) was substituted by the word 'Amount' so that the grammatical interpretation provided by the Court would no longer apply.

(iv) When the $25^{\text {th }}$ Amendment Act was challenged before the Bench in Kesavananda Bharati $^{33}$, the Court was of the view that even though the justiciability of the adequacy of the amount did not abide, the Court would still intervene where the amount was illusory and the principles for fixing the amount were irrelevant. The Court further went on to sustain the $24^{\text {th }}$ Amendment by overruling the decision in Golak Nath.

(v) Cases such as Ranganatha Reddy ${ }^{34}$, and Madan Mohan Pathak ${ }^{35}$ showed that challenges to the law of acquisition on the ground of the contravention of Article 31(2) continued notwithstanding the $25^{\text {th }}$ Amendment.

A note on Kesavananda's case would not be out of place at this juncture, being as it is the most celebrated case in India's constitutional firmament. When the land reforms laws of the State of Kerala were impugned for attempting to interfere with the Petitioner seer's management of his religious temple, it was argued on his behalf that the Constitution contained certain essential features that could not be altered even by exercise of Parliament's constituent power. Interestingly, it was this argument - later to be made famous as the 'basic structure' doctrine - that acknowledged the contribution of a German academic.

Prof. Dieter Conrad was a Head of the Law Department at the South Asia Institute of the University of Heidelberg, who had an opportune occasion to address the Law Faculty of Banaras Hindu University in February 1965 on the issue of "Implied Limitations of the Amending Power". This formed the basis of the arguments of counsel M.K.Nambyar before the Golak Nath court, which were however not accepted. ${ }^{36}$ A few years later, Conrad published a detailed paper on the subject. ${ }^{37}$ Finally, when the implied limitations argument was raised again in Kesavananda's case, they were accepted, thereby carving a via media between the extreme positions of Golak Nath and the Government. The argument that the right to property was a basic feature of the Constitution, and that hence there could be no amendment to that right as it stood, was rejected by the majority of 7 judges, with the remaining 6 finding no merit in the basic structure argument itself. It was but a logical consequence of the actions of the executive in restricting the property rights enjoyed by individuals that resulted in the Constitution ( $44^{\text {th }}$ Amendment) Act, 1978 which wholly annulled the right to property and created severe anomalies in the law.

Kesavananda Bharati v. State of Kerala, (1973) 4 Supreme Court Cases 225. State of Karnataka v. Ranganatha Reddy, (1977) 4 Supreme Court Cases 471. Madan Mohan Pathak v. Union of India, (1978) 2 Supreme Court Cases 50. 


\section{The $44^{\text {th }}$ Amendment}

Close on the heels of the 2-year National Emergency imposed by the majority Congress Government from 1975 to 1977 (which was an era of state excess and suspended human rights), the opposition Janata Party along with its allies formed a coalition Government that sought to reverse the draconian acts of the previous regime. One of the first steps in this direction had been the enactment of the $44^{\text {th }}$ Amendment to the Constitution which sought to negate many aspects of the $42^{\text {nd }}$ Amendment. In this, the Janata Party succeeded, albeit with one glaring error - the deletion of the right to property.

When the Janata party had come to power, a key promise in their election manifesto had been the deletion of the right to property, ostensibly to protect the other rights in Part III from being wantonly amended by subsequent Parliaments. ${ }^{38}$ Speculation has been rife that the only reason for such a wholesale demolition of the property edifice was as a poll arrangement with the communist parties. ${ }^{39}$ Be that as it may, even an examination of the Objects and Purposes of the Amendment Act yields only this:

"3. In view of the special position sought to be given to fundamental rights, the right to property, which has been the occasion for more than one amendment of the Constitution, would cease to be a fundamental right and become only a legal right. Necessary amendments for this purpose are being made to article 19 and article 31 is being deleted. It would, however, be ensured that the removal of property fromthe list of fundamental rights would not affect theright of minoritiestoestablish and administer educationalinstitutions of their choice.

4. Similarly, the right of persons holding land for personal cultivation and within the ceiling limit to receive compensation at the market value would not be affected.

5. Property, while ceasing to be a fundamental right, would, however, be given express recognition as a legal right, provision being made that no person shall be deprived of his property save in accordance with law."

Therefore, in one fell swoop, the right to property was taken from a position of pre-eminence and consigned to being a mere legal right. With the passage of the $44^{\text {th }}$ Amendment, both Articles 19(1)(g) and 31 were deleted, with only the first clause of Article 31 being reproduced elsewhere in the Constitution as Article 300-A.

\section{E. The Fallout}

The result of this Amendment has been evident from the actual problems faced by the nation over the last three decades since then. Stripped of even the right to enforce the enjoyment of property in a court of law, much disgruntlement has set in, particularly among the weaker and less privileged sections of society. Widespread acquisition of land for private purposes and arbitrary licensing policies, have led to a rise in resistance movements in 
India, with violent Marxist nationalism cutting a red swathe across the nation. ${ }^{40}$ Much of this has been attributed to the deprivation of land to the landless. Large infrastructure projects have also been the source of disgruntlement, with issues concerning the Sardar Sarovar Project in Gujarat and Vedanta in Orissa finally receiving their approvals from the Supreme Court of India. As India continues with a high growth rate of over $8 \%$, ${ }^{41}$ substantial local and foreign investment finds its way into highways, airports, housing and power projects. All of these ventures require land, and with local governmental support, many small landholders are deprived of their land for paltry sums of compensation. ${ }^{42}$

Acknowledging the problems that have arisen, Bills have been introduced in Parliament in March 2009, both for the limited basis on which land may be acquired, and for the rehabilitation of those who have been displaced. ${ }^{43}$ Unfortunately, now that the right to property has itself been removed from the hallowed fundamental rights chapter of the Constitution, those aggrieved by the excesses of State action have a very limited recourse to the law, only seeking greater compensation amounts, which also have lost the protection earlier afforded by Article 31 .

\section{F. Doing violence to the spirit of the Constitution}

The $44^{\text {th }}$ Amendment has had a severe impact on the Constitution itself, dealing several blows to its basic structure ${ }^{44}$, amputating the concept of eminent domain and creating glaring inequities. An enquiry into these aspects will lead first to how the deletion of the right would impact the fundamental basis of the Constitution itself.

Present statistics reveal that the 'Naxalites' actually control more than 90,000 square kilometers of the country, and the Indian Prime Minister has stated that is it the most serious threat to India's national security [Statement of the Prime Minister Manmohan Singh of 23.11.2008, from http://www.zeenews.com/news485858.html accessed on 7.3.2011].

41 See http://www.tradingeconomics.com/Economics/GDP-Growth.aspx?Symbol=INR, accessed on 21.3.2011.

Sunita Narain, Another India is [not] ours, Down to Earth, New Delhi, October 31, 2006 at p.5.

43 The Land Acquisition (Amendment) Bill and the accompanying Resettlement and Rehabilitation Bill have been debated among members of the ruling coalition (the United Progressive Alliance (UPA) led by the Congress) in India, with one of the key partners (the Trinamool Congress) opposing the Bills on the ground that no role ought to be given to the State Governments, and that private interests of large industries and corporate houses ought not be equated with public interest. The Bills themselves are aimed at providing a larger role to landowners in consenting to acquisition, and granting alternate land and other remedies, in contrast to the often paltry compensation offered at present.

44 As clarified in Coelho, infra n.47, the basic structure test is applicable to all Constitutional Amendments made after 24.4.1973 (the date of the judgment in Kesavananda Bharati). The Constitution ( $44^{\text {th }}$ Amendment) Act was passed on 30.4.1979 and brought into effect on 20.6.1979. 


\section{I. $\quad$ The Basic Structure}

In Kesavananda, a remark by Justice Khanna, whose judgment reflected the views of the majority, created the impression that while amendments to the Constitution could not breach the basic structure of the Constitution, the fundamental rights themselves were not basic features. Justice Khanna found himself in a position to clarify this misconception later in the case concerning the validity of the election of the Prime Minister. ${ }^{45}$ He said $-{ }^{46}$

\footnotetext{
"There was a controversy during the course of arguments on the point as to whether I have laid down in my judgment in Kesavananda Bharati's case that fundamental rights are not a part of the basic structure of the Constitution. As this controversy cropped up a number of times, it seems apposite that before I conclude I should deal with the contention advanced by learned Solicitor General that according to my judgment in that case no fundamental right is part of the basic structure of the Constitution. I find it difficult to read anything in that judgment to justify such a conclusion. What has been laid down in that judgment is that no article of the Constitution is immune from the amendatory process because of the fact that it relates to a fundamental right and is contained in Part III of the Constitution.

The above observations clearly militate against the contention that according to my judgment fundamental rights are not a part of the basic structure of the Constitution. I also dealt with the matter at length to show that the right to property was not a part of the basic structure of the Constitution. This would have been wholly unnecessary if none of the fundamental rights was a part of the basic structure of the Constitution."
}

While Khanna admittedly observes that he did not believe the right to property a basic feature of the Constitution, that view, as a perusal of Kesavananda will show, was neither sought for, nor supported by the other judges that formed the majority in that case. In fact, as Kesavananda was delivered at a time when the right to property was a part of the Constitution, it was unlikely that the very amputation of a right could have been conceived by that Bench. As a unanimous decision of 9 Judges in 2007 showed $^{47}$, the fundamental rights were never supposed to have been beyond the scope of the basic structure of the Constitution. The Court considered Khanna's subsequent elucidation and said - "Thus, after his aforesaid clarification, it is not possible to read the decision of Khanna, J. in Kesavananda Bharati so as to exclude fundamental rights from the purview of the basic structure". ${ }^{48}$ The Court went further to observe that the basic structure could be found "as reflected in Article 21 read with Article 14 and Article 19". 49

The doctrine of basic structure contemplates that there are certain parts or aspects of the Constitution including Articles $14 \& 15$ (equality), 19 (liberty) and 21 (life) that constitute the core values, which if allowed to be abrogated would change completely the nature of the Constitution. It has been observed that the exclusion of fundamental rights would result

45

46

47

48

49

Indira Gandhi v. Raj Narain, 1975 Supp (1) Supreme Court Cases 1.

Ibid, at Paras 251-252.

I.R.Coelho v. State of Tamil Nadu, (2007) 2 Supreme Court Cases 1.

Ibid, at Para 90.

Ibid, at Para 151. 
in nullification of these essential elements. ${ }^{50}$ With the $44^{\text {th }}$ Amendment, a clause of Article 19 was wholly deleted, which has had an equal impact on the rights protected by Articles 14 and 21 as well.

Subsequent rulings of the Supreme Court show that the pre-eminent position of the fundamental rights has been reinforced. While dealing with a challenge to the accelerated promotions granted to the reserved categories in public services in M.Nagaraj's case ${ }^{51}$, the Court held that "Fundamental rights are not gifts from the State to its citizens, but are basic human rights of intrinsic value. Part III of the Constitution merely confirms their existence and gives them protection." 52 As recently as 2010, in words that would sound the death knell of the $44^{\text {th }}$ Amendment, it was observed - "The fundamental rights, enshrined in Part III of the Constitution, are inherent and cannot be extinguished by any constitutional or statutory provision. Any law that abrogates or abridges such rights would be violative of the basic structure doctrine. The actual effect and impact of the law on the rights guaranteed under Part III has to be taken into account in determining whether or not it destroys the basic structure." 53 Even in particular reference to the right to property, there are recent signs that the Supreme Court is inclined to regard the same as a 'human right', thereby placing it almost on the same pedestal from which it had been dislodged. ${ }^{54}$ All of these judgments have been delivered after the clarification in I.R.Coelho 55 that fundamental rights would indeed be a part of the basic structure of the Constitution. Human rights are the most integral and necessary principles upon which individuals live in a society. If property is considered to be a vestige of such rights, it cannot possibly be said that it is not a basic feature of the Constitution.

50

51

52

53

54

Ibid, at Paras 141, 145, 151(iii)-(v).

M.Nagaraj v. Union of India, (2006) 8 Supreme Court Cases 212

Ibid, at Para 20.

State of W.B. v. Committee for Protection of Democratic Rights, (2010) 3 Supreme Court Cases 571 at Para 68.

As many as nine judgments of the Supreme Court in the last 4 years have held that the "right to property is a human right":

-Hemaji Waghaji Jat v. B.K.Harijan, (2009) 16 Supreme Court Cases 517

-Union of India v. Martin Lottery Agencies, (2009) 12 Supreme Court Cases 209

- State of Kerala v. PUCL, (2009) 8 Supreme Court Cases 46

-Aslam Mohammad Merchant v. Competent Authority, (2008) 14 Supreme Court Cases 186

-Entertainment Network v. Super Casette, (2008) 13 Supreme Court Cases 30

- KSFC v. N.Narasimhaiah, (2008) 5 Supreme Court Cases 176

-Vimlaben Patel v. Vatslaben Patel, (2008) 4 Supreme Court Cases 649

-Indore Vikas Pradhikaran v. Pure Industrial Coke \& Chemicals, (2007) 8 Supreme Court Cases 705

•P.T. Munichikkanna Reddy v. Revamma, (2007) 6 Supreme Court Cases 59

Supra, n. 47 


\section{Eminent Domain}

As the discussion above has shown, Article 31 was the embodiment of the principle of eminent domain in India. With such a historically well-entrenched principle, there was little reason to depart from its initial underpinnings, and it was with this common understanding that the provision was formulated upon at the Constitutional Assembly. From the time that Runnymede was made famous till the House of Lords upheld the English regent's right to acquire saltpetre for his ammunition ${ }^{56}$ and thereafter, it has been universally accepted that the State has the right to acquire private property for a public purpose, and upon just recompense. $^{57}$ The payment of compensation for exercise of eminent domain powers is well entrenched in international jurisprudence as is evident from the following:

-English Magna Carta 1215 - Chapter 28

-Declaration of the Rights of Man and of the Citizen 1789 [France]

-Bill of Rights 1791 [USA]

-Universal Declaration of Human Rights 1948 - Article 17

-Protocol No.1 to the European Convention on Human Rights 1952 -Article 1

-United Nations General Assembly Resolution on Permanent Sovereignty over Natural Resources 1962 - Paragraph 4

-International Covenant on Political and Civil Rights 1966 - Articles 1, 26 and 27

-American Convention on Human Rights 1969 (also known as the Pact of San José) Article 21

- Charter of Economic Rights and Duties of States 1974 - Article 2

-United Nations Convention on the Elimination of All Forms of Discrimination against Women 1979 - Articles 15 and 16

-African Charter on Human Rights and Peoples' Rights 1986 - Articles 13 and 14

Initially Article 31 consisted of 6 sub-clauses, where Article 31(1) laid down the protection against deprivation of private property without following the procedure laid down by law, and Article 31(2) provided the safeguard of compensation necessarily having to be paid in the event of such taking of property. This extended to both movable and immovable property. However, the $44^{\text {th }}$ Amendment succeeded in creating an unprecedented anomaly. While the entirety of Article 31 was deleted from Part III with the intention of reproducing

One the major milestones in the evolution of eminent domain, this case concerned a law enacted by King James I of England allowing the crown to acquire saltpeter which was required for the armoury. The House of Lords rejected the challenge of the subject and held that such taking in public interest with due payment was permissible in law. This is reported as The King's Prerogative in Saltpetre, (1606) 12 Co. Rep. 12. It is curious to note that it was just a few weeks earlier that gunpowder had played another significant role - the capture of Guy Fawkes below the Houses of Parliament that he was seeking to blow up on $5^{\text {th }}$ November, 1605.

57 This is premised on two principles (1) The people's welfare is paramount (Salus populi est suprema lex) and (2) Public need is greater than private need (Necessitas publica major est quam private). 
it elsewhere in the Constitutional text, eventually only Article 31(1) found itself reincarnated as Article $300-\mathrm{A}^{58}$, while all the remaining sub-clauses including the assurance of compensation contained in Article 31(2) were omitted. As a consequence, the Constitution today permits a law to acquire private property, with no requirement to pay compensation. Any argument that the right to compensation need not be spelt out as it inheres in other provisions of the Constitution (right to life; right against arbitrary action) ${ }^{59}$, has been effectively rejected by virtue of the judgment of the Supreme Court in Jilubhai ${ }^{60}$ where it has been observed: ${ }^{61}$

"By necessary implication the obligation of the State to pay compensation for property acquired or indemnification of property deprived under Article 300-A or other public purpose is obviated."

Even in the provinces, this position has been reinforced. In Bihar, a challenge to the Debt Relief Act, 1977 on the ground that it provided for no compensation was rejected when Article 300-A was invoked. ${ }^{62}$

The prominent Constitutional commentator H.M.Seervai has commented on this grave omission in the following words: ${ }^{63}$

"The rights conferred by Article 19(1)(f) and Article 31 (read with the entries in the Legislative Lists regarding acquisition and requisition of property) were so closely interwoven with the whole fabric of our Constitution that those rights cannot be torn out without leaving a jagged hole and broken threads. The hole must be mended and the broken threads replaced so as to harmonise with the other parts of our Constitution. The task is not easy, and the courts will be called upon to answer problems more formidable than those raised by Article 31 after it was amended a number of times."

Several other experts on the Indian Constitution have all been united in their criticism of the deletion by the $44^{\text {th }}$ Amendment, and that it was only to fulfill an electoral pledge of the Janata party and for no other reason. ${ }^{64}$

By deleting the right to compensation available in Article 31(2), the $44^{\text {th }}$ Amendment also results in discriminations at as many as three levels, all of which violate the equality code

58

59

60

61

62

63

64

Article 300-A: "No person shall be deprived of his property save by authority of law."

As has been argued by both P.K. Tripathi, Right to Property after Forty Fourth Amendment Better protected than ever before, Vol. 67, All India Reporter (Journal), 49, and H.M.Seervai, Constitutional Law of India, Fourth Edition, Vol. II, Bombay 2007, pp. 1354-1427.

1995 Supp (1) Supreme Court Cases 596.

Ibid, at Para 53.

Ishwar Das Murlidhar v. State of Bihar, All India Reporter 1983 Patna 281.

Supra n.56, at pp. 1357-1358.

Austin, supra n.25, at pp. 420-430; Durga Das Basu, Shorter Constitution of India, Thirteenth Edition, Nagpur 2001, pp. 1270-1271; F.S.Nariman, Freedom to acquire hold and dispose of Property, in: Mohammed Hidayatullah (ed.), Constitutional Law of India, Vol. I, New Delhi 1984, at pp. 396-398. 
and once again occasion a breach of the basic structure of the Constitution. While compensation is no longer a right to a deprived property owner covered by Article 300-A:

-an amount of compensation would still be paid to the property owner of a minority institution [Article 30(1A)];

-market value compensation would have to be paid to an estate owner who personally cultivates his land within the ceiling limit [Article 31-A second proviso]; and

-no compensation need be paid to a landless peasant who tills the land of another.

The above circumstance leads to discriminations between majority and minority communities, between personal holders of land and actual tillers and between the agrarian rich and rural poor. This is not only anomalous, but wholly against the ideals of the Constitution enshrined in the Directive Principles, particularly with reference to economic and social justice. The inequities that are fostered as a result of this Amendment are patently obvious due to the retention of other Constitutional provisions which enjoin the payment of compensation in certain circumstances. Such inconsistency would strike at the root of the equality code and cause serious damage to the basic structure. The Supreme Court has repeatedly affirmed that equality itself is a basic feature of the Constitution. ${ }^{65}$

\section{G. A Caveat}

While much of the debate concerning the right to property has revolved around the issue of land and the various reform legislations introduced post-Independence, the concept of 'property' includes immoveable and intangible objects as well. Over the years, the scope of the protection of Article 31 and Article 19(1)(f) has widened considerably due to judicial interpretation. ${ }^{66}$ It must be remembered that Article 32 was the avenue utilized to approach the Supreme Court directly against the violation of fundamental rights. The consequence of the $44^{\text {th }}$ Amendment was that there was no further right to approach the Supreme Court

Maharao Bhim Singhji \& Ors. v. Union of India \& Ors., (1981) 1 Supreme Court Cases 166 at Para 21; M.Nagaraj v. Union of India, (2006) 8 Supreme Court Cases 212 at Para 4; Umadevi v. State of Karnataka, (2006) 4 Supreme Court Cases 1 at Paras 43 \& 45; T.M.A.Pai Foundation v. State of Karnataka, (2002) 8 Supreme Court Cases 481 at Para 404;

66

All the following have been held to be property:

(i) Choses-in-action [Madan Mohan Pathak v. Union of India, (1978) 2 Supreme Court Cases 50]

(ii) Debts owed to creditors [R.C.Cooper v. Union of India, (1970) 1 Supreme Court Cases 248]

(iii) Privy purses [Madhav Rao Scindia v. Union of India, (1971) 1 Supreme Court Cases 85]

(iv) Right to cash grants from the State [State of MP v. Ranajirao Shinde, (1968) 3 Supreme Court Rerporter 48]

(v) Pension [Deokinandan Prasad v. State of Bihar, (1971) 2 Supreme Court Cases 330 \& State of Punjab v. K.R.Erry, (1973) 1 Supreme Court Cases 120]

(vi) Unpaid accumulations to employees [State of Gujarat v. Ambica Mills, (1974) 4 Supreme Court Cases 656]

(vii) Intellectual property rights [Entertainment Network v. Super Cassette, (2008) 13 Supreme Court Cases 30] 
when the right to property was infringed by State action. Due to the wide interpretation favoured by the courts, aged pensioners and hapless creditors are also deprived of their right to approach the Supreme Court, and relegated forcibly to take other recourse.

\section{H. Epilogue or Epitaph?}

There is little hope for a retrieval of the right that has now been lost. It has been 34 years since the passing of the Constitution Amendment, and although a challenge to it was filed belatedly in 2007, that was dismissed at the threshold in late $2010^{67}$. The illegalities which were a consequence of the Amendment still stand, and as Governments exploit this new found power over private property, more deprivation occurs, which leads to a greater disenchantment among the citizens. The Constitution as envisaged did little wrong, but the course adopted by subsequent Governments have been flawed. In its zeal to subvert judicial dictum, the power of Constitutional Amendment has been liberally exercised - one which ought to have been applied with the greatest restraint, and only nominally.

The Supreme Court has however been endowed with wide and far-reaching powers, and it has applied these often to rectify errors by the other wings of Government. While such power of review is exercised occasionally, its very scope has been expanded through judicial interpretation. As a result, the Court today is one of the most powerful superior courts anywhere in the world. If it obtains a will to bring about reform, the status quo could be restored with a little bit of imagination and a lot of conviction.

Till then, whether the right to property is dead, or merely dormant is a question that must remain to be answered.

67 Sanjiv Kumar Agarwal v. Union of India, Writ Petition (c)No.464/2007 disposed off on $18^{\text {th }}$ October 2010. 